\title{
Comparison of bread wheat varieties with different breeding origin under organic and low input management
}

\author{
Péter Mikó • Franziska Löschenberger · Jürg Hiltbrunner • \\ Rosalie Aebi · Mária Megyeri • Géza Kovács • \\ Márta Molnár-Láng · Gyula Vida · Marianna Rakszegi
}

Received: 29 November 2013/ Accepted: 28 May 2014/Published online: 17 June 2014

(C) The Author(s) 2014. This article is published with open access at Springerlink.com

\begin{abstract}
In recent years needs have increased to investigate the necessity of breeding cereals for organic agriculture. The aims of this study were (1) to compare 37 bread wheat (Triticum aestivum L.) varieties with different breeding origin under low input conventional and certified organic farming conditions in Austria and Hungary for 3 years, (2) to identify traits highly sensitive to management systems that could be separated according to their suggested selecting environments and (3) to find evidence for the distinctness of organic wheat breeding. According to the results, seven out of the 15 traits assessed during this study showed significant management $\times$ genotype interaction meaning that these traits could be the basis of selection for different management systems.
\end{abstract}

Electronic supplementary material The online version of this article (doi:10.1007/s10681-014-1171-8) contains supplementary material, which is available to authorized users.

P. Mikó $(\bowtie) \cdot$ M. Megyeri · G. Kovács ·

M. Molnár-Láng · G. Vida · M. Rakszegi

Agricultural Institute, Centre for Agricultural Research,

Hungarian Academy of Sciences, Brunszvik u. 2,

2462 Martonvásár, Hungary

e-mail: miko.peter@agrar.mta.hu

F. Löschenberger

Saatzucht Donau GmbH \& Co KG, Saatzuchtstrasse 11, 2301 Probstdorf, Austria

J. Hiltbrunner · R. Aebi

Agroscope, Institut für Pflanzenbauwissenschaften IPB,

Reckenholzstrasse 191, 8046 Zurich, Switzerland
Heading date, sensitivity to leaf rust and powdery mildew had high repeatabilities. For economic reasons, it is therefore reasonable to select for these traits in conventional fields even if the selection target is organic agriculture. However, the present study suggests that selection for the other four traits (grain yield, test weight, leaf-inclination and vigorous growth during booting) should be done later in the target environment. The study compared groups of varieties developed by different breeding strategies (organic, conventional and combined strategies). The results of multivariate analyses showed that the organic breeding was distinct from the other two breeding strategies, but the combined and conventional breeding resulted in similar groupings. It is concluded that the selecting environment has measurable effects on the performance of bread wheat varieties under organic and low input growing conditions.

Keywords Low input - Organic agriculture · Organic breeding $\cdot$ Triticum aestivum $\cdot$ Variety performance

$\begin{array}{ll}\text { Abbreviations } \\ \text { BFOA } & \text { Breeding For Organic Agriculture } \\ \text { E } & \text { Environment } \\ \text { G } & \text { Genotype } \\ \text { GPC } & \text { Grain Protein Content } \\ \text { GY } & \text { Grain Yield } \\ \text { HD } & \text { Heading Date }\end{array}$


INC INClination of leaves at booting

LI Low Input (refers to low input conventional field)

LOD LODging

LR Severity of disease symptoms of Leaf Rust

M Management

O Organic (refers to organic field)

OA Organic Agriculture

PH Plant Height

PM Severity of disease symptoms of Powdery Mildew

REML REstricted Maximum Likelihood algorithm: estimates variance parameters in linear mixed models

SCB Soil Coverage at Booting

SCT Soil Coverage at the end of Tillering

TAR TARdiness of growth during booting (refers to vigorousness)

TILL Number of TILLers before stem elongation

TKW Thousand Kernel Weight

TW Test Weight

VCU Value for Cultivation and Use

VG Variety-Group consisting of varieties developed with the same breeding strategy

WH Winter Hardiness

\section{Introduction}

Farmers who are following the regulations [Council Regulation (EC) 2007, No. 834/2007] of the rapidly developing organic agriculture (OA) movements have to endeavour to use organic seeds (Döring et al. 2012), but the ensuing demand is met in $95 \%$ with organically produced seed from varieties that were bred for conventional agriculture. Conventional plant breeding has mainly relied on selection with strongly limited environmental variability, because the selection environment is usually stabilised using artificial fertilizers, herbicides and other chemicals against pests and diseases (usually in the late generations) (Lammerts van Bueren et al. 2010). Therefore, the performance of conventionally bred varieties is often different in other environments with lower inputs due to genotype $\times$ environment $(G \times E)$ interactions. Recently several studies revealed that it is important to evaluate traits of varieties both under conventional and organic management conditions in order to investigate traits useful in organic breeding (Wolfe et al. 2008;
Löschenberger et al. 2008; Lammerts van Bueren et al. 2010). Winter bread wheat (Triticum aestivum L.) is one of the most important crops worldwide, therefore many studies have used it in organic breeding approaches, where specific characters (e.g. yield stability, weed suppression, disease resistance, tolerance to harrowing, nutrient use efficiency or specific product quality) were examined (Löschenberger et al. 2008). According to European directive 70/457/EEC (1970), marketable seeds can be produced only from varieties that belong to the official variety list of the EU or one of its countries. The common Value for Cultivation and Use (VCU) test is designated to examine which variety could be put on these lists. Generally, VCU trials are carried out in conventional fields, thus important traits for OA are not on the checklist and they remain unexamined (Lammerts van Bueren et al. 2010). However, in recent years an increasing number of EU countries has already started VCU tests on cereals especially for organic farming under organic growing conditions, where the traits important for OA were also examined, though in most cases conventional VCU has to be also accomplished (except Austria, France and Germany) before the release of an organic variety (Menzi and Anders 2002; Oberforster 2003; Schwaerzel et al. 2006; Wolfe et al. 2008). Characteristics with particular relevance for $\mathrm{OA}$, such as weed suppression ability are often hard to measure in a commercial plant breeding context, but they could be also evaluated indirectly through traits as plant growth habit, leaf inclination and plant height (Eisele and Köpke 1997; Hoad et al. 2005). The main target of organic breeding is to find characters that could positively affect the general variety performance in OA (Wolfe et al. 2008). For example, vigorous early plant growth could result in better weed suppression, better utilization of nutrients in early growth stages and better resistance to pests and diseases (e.g. bunt species).

International experiments have been established in order to examine conventional bred wheat varieties under different management systems in European organic and conventional fields (Baresel and Reents 2006; Löschenberger et al. 2008; Przystalski et al. 2008). As organic VCU tests have been carried out in some western European countries for more than a decade, organic varieties and varieties bred by a combined strategy, the Breeding For Organic Agriculture (BFOA) strategy (bred partly in conventional 
field but especially for OA and registered after organic VCU test) had already been released. This made it possible to start studies also on the effects of different breeding strategies. The aims of this study were (1) to compare bread wheat varieties with different breeding origin under low input conventional and certified organic farming conditions in two countries, (2) to identify traits highly sensitive to management systems that could be separated according to their suggested selecting environments and (3) to test where there is any evidence for the distinctness of organic wheat breeding.

\section{Materials and methods}

\section{Plant material}

In the present study 37 winter bread wheat (Triticum aestivum L.) varieties and advanced lines were examined. Varieties originated from Austria, France, Germany, Hungary and Switzerland had different breeding origin: one part (nine varieties) of the varieties originated from organic breeding, i.e. selection took place only in organic systems; 20 varieties were bred under conventional growing conditions and eight varieties were bred partly in conventional field but especially for OA (selection in early generations was in conventional but later selection in organic systems) and were registered after organic VCU test (BFOA varieties). Varieties were chosen for these three variety-groups (VGs) to represent different countries of origin, years of release and quality groups in each VG (Suppl. Table 1).

\section{Field experiment}

Between 2011 and 2013 the same 37 bread wheat varieties were examined in Austria (A) and Hungary (H) using randomized complete block design with three replications of the small plots (Austria: $9 \mathrm{~m}^{2}$ / plot, Hungary: $6 \mathrm{~m}^{2} /$ plot) under organic $(\mathrm{O})$ and low input (LI) growing conditions (a total of four trial locations: AO, ALI, HO and HLI). In both countries the $\mathrm{O}$ and LI sites were very close to each other to minimize confounding effects of differences in soil and microclimatic conditions. The trial plots (row distance $0.15 \mathrm{~m}$ ) were machine-planted (HEGE-80 plot driller) and combine-harvested (Wintersteiger plot combine). Herbicides, insecticides and artificial fertilizers were used in the low input fields when necessary, but fungicides not. The weather conditions differed greatly not only between the years but also between the countries. In addition, due to the different climatic conditions highly different sowing density was applied in the two countries; therefore, a total of six sites ( 3 years $\times 2$ countries) were examined as different environments $(\mathrm{E})$ for the differences between the management systems $(\mathrm{O}$ and $\mathrm{LI})$.

In order to emphasise the differences between the wheat varieties in nutrient use efficiency, sites with relatively low nutrient input had to be chosen for the present study. In the low input fields of the ring test the nitrogen was supplied with different quantities of mineral fertilizers. However, it is hard to express the nutrient supply of the organic locations in amounts of active ingredients, because it was assured only by previous crops (mainly legumes). After the moderately dry first season of 2010/2011, year 2012 brought an extreme drought which was followed by an average season in 2013. In most cases the Hungarian locations got less precipitation and were warmer than the Austrian ones. Further growing and management parameters of the trial locations are detailed in Suppl. Table 2.

\section{Assessment of agronomic traits}

Field assessment (and examination of the harvested grains) was carried out according to the same list of characters in both countries (Table 1). Three traits [soil coverage at two stages (end of tillering: SCT; booting: SCB) and leaf-inclination at booting (INC)] from the 15 traits assessed are additionally measured/ scored in organic VCU tests compared to the conventional VCU test. Severity of the disease symptoms of leaf rust (Puccinia triticina Erikss.; LR) and powdery mildew [Blumeria graminis (DC.) Speer; PM] was assessed as an indicator of resistance in the years when these diseases could be observed. The maximum plant height (PH) and lodging (LOD) were determined 1 day before harvest, while other traits [winter hardiness (WH) and heading date (HD)] were assessed during the growing period, including important traits for OA, such as tillering ability (TILL) and vigorous growth at booting (TAR). For practical reason, the vigorousness was scored contrarily: the more vigorous genotypes got lower scores, and the tardier genotypes 
Table 1 Agronomic traits assessed in the trial of 37 winter bread wheat varieties in organic $(\mathrm{O})$ and low input (LI) fields of Hungary (H) and Austria (A) for 3 years between 2011 and 2013

\begin{tabular}{|c|c|c|c|c|c|c|c|}
\hline \multicolumn{2}{|c|}{ Traits measured or scored (value or score) } & \multirow[t]{2}{*}{ Implementation of measurement or scoring } & \multicolumn{5}{|c|}{$\begin{array}{l}\text { Number of assessments* } \\
\text { (2011-2013) }\end{array}$} \\
\hline Abbreviation & Description & & $\mathrm{HO}$ & HLI & $\mathrm{AO}$ & ALI & Total \\
\hline WH & Winter hardiness (1-9) & $1=$ very good, $9=$ dead after winter & 3 & 3 & 6 & 6 & 18 \\
\hline TILL & $\begin{array}{l}\text { Number of tillers before } \\
\text { stem elongation (number) }\end{array}$ & Counting of tillers on 5 plants/plot & 3 & 3 & 9 & 6 & 21 \\
\hline SCT & $\begin{array}{l}\text { Soil coverage at the end of } \\
\text { tillering }(\%)\end{array}$ & $\begin{array}{l}\text { Estimation of percentage (100\% minus percentage of } \\
\text { visible soil) }\end{array}$ & 3 & 3 & 6 & 3 & 15 \\
\hline INC & $\begin{array}{l}\text { Inclination of leaves at } \\
\text { booting (1-9) }\end{array}$ & $1=$ upright, $9=$ curved & 3 & 3 & 5 & 3 & 14 \\
\hline TAR & $\begin{array}{l}\text { Tardiness of growth during } \\
\text { booting }(1-9)\end{array}$ & $\begin{array}{l}\text { Tardiness refers to vigorous growth, therefore } \\
1=\text { very vigorous, } 9=\text { late, non-vigorous }\end{array}$ & 3 & 3 & 6 & 9 & 21 \\
\hline SCB & $\begin{array}{l}\text { Soil coverage at booting } \\
(\%)\end{array}$ & $\begin{array}{l}\text { Estimation of percentage (100\% minus percentage of } \\
\text { visible soil) }\end{array}$ & 5 & 5 & 3 & 3 & 16 \\
\hline HD & Heading date (number) & $\begin{array}{l}\text { Number of days after April 30th until heading of } \\
50 \% \text { of the plants }\end{array}$ & 3 & 3 & 9 & 9 & 24 \\
\hline PM & $\begin{array}{l}\text { Susceptibility to powdery } \\
\text { mildew (1-9) }\end{array}$ & $\begin{array}{l}\text { Severity of disease symptoms as an indicator of } \\
\text { resistance: } 1=\text { resistant, } 9=\text { totally susceptible }\end{array}$ & 1 & 2 & 3 & 9 & 15 \\
\hline LR & $\begin{array}{l}\text { Susceptibility to leaf rust } \\
\text { (1-9) }\end{array}$ & $\begin{array}{l}\text { Severity of disease symptoms as an indicator of } \\
\text { resistance: } 1=\text { resistant, } 9=\text { totally susceptible }\end{array}$ & 2 & 2 & 6 & 3 & 13 \\
\hline LOD & Lodging (1-9) & $1=$ upright, $9=$ totally lodged & 3 & 3 & 1 & 3 & 10 \\
\hline $\mathrm{PH}$ & Plant height $(\mathrm{cm})$ & Measurement from ground to top of canopy & 9 & 9 & 9 & 9 & 36 \\
\hline GY & Grain yield (t/ha) & $\begin{array}{l}\text { Derived from harvested } \mathrm{kg} \text { of grains/plot values } \\
(10-12 \% \text { moisture content) }\end{array}$ & 9 & 9 & 9 & 9 & 36 \\
\hline TKW & Thousand kernel weight (g) & Derived from the weight of $4 \times 200$ seeds & 6 & 7 & 5 & 6 & 24 \\
\hline TW & Test weight $(\mathrm{kg} / \mathrm{hl})$ & Weight of seeds in 11 and multiplied by 100 & 6 & 7 & 5 & 6 & 24 \\
\hline GPC & Grain protein content $(\%)$ & Percentage in dry matter content of the grains & 6 & 7 & 5 & 6 & 24 \\
\hline
\end{tabular}

* Each trial plot had 3 replications, therefore 9 is the maximum number of assessments/location over 3 years, and 36 for total

got higher scores. Therefore, varieties with the lowest TAR scores represent the most vigorous ones. Grain yield (GY) of each plot was determined after drying for 1 week to correct the differences in grain moisture content of the different locations.

Before the end of the given year the harvested grains were examined for protein content, thousand kernel weight (TKW) and test weight (TW) determined by the weight $(\mathrm{kg})$ of the given seeds filled up a container of $0.1 \mathrm{~m}^{3}$ with. Grain protein content (GPC) was determined by Foss Tecator 1241 with Near Infrared Spectroscopy (NIR) method according to ICC 202 and ICC 159 standards. TKW was measured with Perten SKCS 4100 using the standard AACC Method 55-31, and TW was determined also by Foss Tecator 1241.
The lowest number of assessments conducted over the entire set of trials was for LOD, which occurred mainly in 2011 giving only a total of 10 replications to compare for each variety. The occurrence of fungal diseases was also strongly dependent on the year and site effect, therefore LR and PM could be scored only 13 and 15 times, respectively. Soil coverage (SCT and $\mathrm{SCB}$ ) and INC were also assessed less than half of the assessment occasions, while other traits were assessed more than half of the maximum 36 occasions. Despite the fact that the total number of trial plots assessed by most of the traits was less than the maximum (average number of assessments for one evaluated trait regarding a given variety was 21 ), it did not reduce the effectiveness of the statistical tests used in the present study. 
Statistical analysis

Statistical evaluations were carried out using SPSS 16.0 software (SPSS Inc., Chicago, IL, USA). The first statistical model was imported in the Linear Mixed Model (using the restricted maximum likelihood algorithm, REML) analysis module based on the study of Virk et al. (2009) with some modifications published by Vida et al. (2014):

1. Fixed model $=$ Constant $+\mathrm{E}+\mathrm{M}+\mathrm{G}+\mathrm{E} \times$ $\mathrm{M}+\mathrm{E} \times \mathrm{G}+\mathrm{M} \times \mathrm{G}+\mathrm{E} \times \mathrm{M} \times \mathrm{G}$

Random model $=$ Replication

where E represents the total of six sites of the two countries (environments), $M$ represents the two management systems ( $\mathrm{O}$ and LI), $\mathrm{G}$ represents the 37 bread wheat genotypes and Replication was used as random factor in the mixed model.

A second model was used for the traits that showed significant $\mathrm{M} \times \mathrm{G}$ interaction based on the first model in order to evaluate the repeatability and genotypic variance and the variance of $\mathrm{G} \times \mathrm{E}$ interaction of the traits separately in the two management systems. Repeatability was calculated as the ratio of genotypic to phenotypic variance. This kind of evaluation was proved to be an effective tool to discriminate genotypes regarding different traits through different environments (e.g. Presterl et al. 2003; Cormier et al. 2013; Longin et al. 2013). The model was the following:

2. Random model $=$ Constant $+\mathrm{E}+\mathrm{G}+\mathrm{G} \times$ $\mathrm{E}+\varepsilon$

where $\mathrm{E}$ is the environment (6 levels), $\mathrm{G}$ is the genotype (37 levels), $\mathrm{G} \times \mathrm{E}$ is the interaction between them and $\varepsilon$ is the residual error term.

Correlations between all the 15 traits assessed in the present study were analysed using the Bivariate Correlations analysis module of SPSS 16.0 software. Correlation of traits regarding the two management systems were determined on the basis of Pearson's correlation coefficient using the best linear unbiased estimators (BLUEs) of the traits generated by the mixed model 1. Demonstration of the correlation coefficients was based on the paper of Longin et al. (2013) and the strength of correlations was determined according to Evans (1996), who suggests five groups of strength based on the absolute value of the correlation coefficient (r): very weak (0.00-0.19), weak (0.20-0.39), moderate $(0.40-0.59)$, strong (0.60-0.79) and very strong (0.80-1.00).

Discriminant Analysis was used in the SPSS 16.0 software in order to examine the severability of the 37 winter wheat genotypes in the two different management systems based on their breeding origin. In this evaluation average values of the traits assessed on the six sites ( 3 years $\times 2$ countries) were used for each management system.

\section{Results}

In the present work 15 traits were assessed on 37 bread wheat varieties through 3 years grown under two different management conditions, organic (O) and low input conventional (LI). First aim was to examine the main effects and their interactions tested by Chi squared values in the REML analysis for the traits (Table 2). Large significant environmental (E) and genotypic (G) effects were observed in the case of all traits. However, the effect of management (M) was less emphasised and was not significant in the case of $\mathrm{WH}$, SCT, SCB, INC and GPC. Only soil coverage assessed in two growing stages (SCT and SCB) had no significant respond in the case of $\mathrm{E} \times \mathrm{G}$ interactions, while $\mathrm{E} \times \mathrm{M}$ interaction was found to be strongly significant regarding all of the traits assessed. The $\mathrm{M} \times \mathrm{G}$ interactions related to the traits show which traits are different under $\mathrm{O}$ and LI growing conditions when taking also into account the effects of the different varieties.

\section{Genotypic variance and repeatability}

According to Table 2 seven traits could be selected that could be useful in discriminating the varieties based on their performance in $\mathrm{O}$ and LI fields, because they showed significant differences for $\mathrm{M} \times \mathrm{G}$. With these traits the genotypic variance and repeatability approaches could be carried out regarding the two manage ment systems. Mean values and the corresponding variance components split by management systems are shown in Table 3 (mean values and standard deviations for all the 15 traits split by management systems and VGs are presented in Suppl. Table 3). In average of the 37 trial entries of all the 6 sites the organic management resulted in $5 \%$ less GY (4.38 t/ha in O field, and $4.61 \mathrm{t} / \mathrm{ha}$ in LI field) and in $3 \%$ lower TW $\left(80.13 \mathrm{~kg} / 0.1 \mathrm{~m}^{3}\right.$ in $\mathrm{O}$ field, and $82.37 \mathrm{~kg} / 0.1 \mathrm{~m}^{3}$ 
Table 2 Significance of the main effects and their interactions tested by Chi squared ( $\mathrm{F}=$ Wald statistic/d.f.) values in the linear mixed model for traits assessed in the ring test of 37 winter bread wheat varieties (37 genotypes) in organic and low input conventional fields (2 management systems) of Austria and Hungary between 2011 and 2013 (6 environments)

\begin{tabular}{|c|c|c|c|c|c|c|c|}
\hline Trait & Environment (E) & Management (M) & Genotype (G) & $\mathrm{E} \times \mathrm{M}$ & $\mathrm{E} \times \mathrm{G}$ & $\mathrm{M} \times \mathrm{G}$ & $\mathrm{E} \times \mathrm{M} \times \mathrm{G}$ \\
\hline WH & $116.69 * * *$ & 0.08 & $8.80 * * *$ & $9.77 * * *$ & $5.64 * * *$ & 0.93 & $1.39 * *$ \\
\hline TILL & $69.90 * * *$ & $10.46^{* *}$ & $10.76^{* * *}$ & $8.55 * * *$ & $3.24 * * *$ & 0.75 & 1.00 \\
\hline SCT & $170.55 * * *$ & 0.34 & $3.13 * * *$ & $33.58 * * *$ & 1.26 & 1.11 & $1.40 *$ \\
\hline INC & $42.87 * * *$ & 0.94 & $13.68 * * *$ & $8.78 * * *$ & $4.31 * * *$ & $2.92 * * *$ & $3.54 * * *$ \\
\hline TAR & $539.51 * * *$ & $22.81 * * *$ & $31.91 * * *$ & $46.03 * * *$ & $9.71 * * *$ & $2.69 * * *$ & $2.32 * * *$ \\
\hline SCB & $67.99 * * *$ & 0.56 & $1.74 * *$ & $44.88 * * *$ & 0.76 & 0.37 & 0.32 \\
\hline HD & $2,483.87 * * *$ & $5.89 *$ & $220.95 * * *$ & $142.75 * * *$ & $4.96 * * *$ & $1.69 * *$ & $2.37 * * *$ \\
\hline PM & $29.39 * * *$ & $7.07 * *$ & $17.27 * * *$ & $166.72 * * *$ & $2.02 * * *$ & $2.30 * * *$ & $2.73 * * *$ \\
\hline LR & $92.83 * * *$ & $3.95 *$ & $16.02 * * *$ & $16.93 * * *$ & $2.52 * * *$ & $2.23 * * *$ & 1.12 \\
\hline LOD & $101.47 * * *$ & $43.02 * * *$ & $4.88 * * *$ & $103.05 * * *$ & $2.40 * * *$ & 1.39 & $2.87 * * *$ \\
\hline $\mathrm{PH}$ & $2,027.50 * * *$ & $152.51 * * *$ & $105.98 * * *$ & $169.65 * * *$ & $2.56 * * *$ & 1.125 & 0.97 \\
\hline GY & $2,162.11 * * *$ & $56.50 * * *$ & $10.89 * * *$ & $419.13 * * *$ & $2.86 * * *$ & $1.91 * *$ & $1.44 * * *$ \\
\hline TKW & $244.06 * * *$ & $36.77 * * *$ & $25.05^{* * *}$ & $28.36 * * *$ & $2.74 * * *$ & 0.74 & 1.19 \\
\hline TW & $339.10 * * *$ & $262.84 * * *$ & $46.62 * * *$ & $161.18 * * *$ & $19.74 * * *$ & $29.53 * * *$ & $30.64 * * *$ \\
\hline GPC & $787.21 * * *$ & 2.27 & $14.55^{* * *}$ & $126.53 * * *$ & $1.25^{*}$ & 0.75 & 1.10 \\
\hline
\end{tabular}

$*, * *, * * *$ significant at the $0.05,0.01,0.001$ probability level, respectively

in LI field), but PM scores were $22 \%$ higher in LI system. Average values of the other traits were almost the same in both management systems, but the organic site had slightly higher deviations.

Genotypic variance and variance of $\mathrm{G} \times \mathrm{E}$ were significant for all the traits in the low input system, except the $G \times E$ interaction of LR. However, in the case of the organic management system, significant genotypic variance was not found for INC and TW. These two traits also showed large differences in repeatability on the $\mathrm{O}$ and LI fields, because values for LI were more than two times higher than that of $\mathrm{O}$. Repeatability values of the other traits were relatively high ranging from 0.66 to 0.98 in LI field and from 0.76 to 0.98 in O field. Values of well heritable traits (HD, PM and LR) were over 0.87 in both management systems (as expected), while GY was found to have higher repeatability under organic (0.85) than under low input conditions (0.70) for the same set of varieties. This difference is in line with the almost doubled residual variance component of the LI field.

\section{Correlation among traits}

Pair-wise correlations among the 15 traits were mostly similar in both management systems, but in some cases the strength of the correlations was different
(Table 4). The correlation coefficients (r) were found to be highly significant at the 0.001 probability level for correlation-strength equal or higher than weak $(0.20<\mathrm{r})$, except the correlation between TW and PM on organic field.

The expected very strong positive correlation was detected between the two stages of soil coverage (SCT and $\mathrm{SCB}$ ) in $\mathrm{O}$ field and this correlation was also remarkable in LI field ( $\mathrm{r}=0.80$ for $\mathrm{O}$ and $\mathrm{r}=0.58$ for LI). Examining the moderate or higher strength of correlations $(0.40<\mathrm{r})$, two $\mathrm{PH}$-connected and five GY-connected correlations were detected having this correlation-strength both in $\mathrm{O}$ and LI fields. $\mathrm{PH}$ correlated moderate-strong positively with LOD ( $\mathrm{r}=0.64$ for $\mathrm{O}$ and $\mathrm{r}=0.56$ for $\mathrm{LI}$ ) and with TKW ( $r=0.53$ for $\mathrm{O}$ and $\mathrm{r}=0.54$ for $\mathrm{LI}$ ), while GY had positive (with $\mathrm{PH}, \mathrm{HD}$ and TKW) and negative (TAR and GPC) correlations on the strength level of moderate and strong. The positive correlation between GY and PH was determined as moderate in $\mathrm{O}$ $(\mathrm{r}=0.42)$ and as strong in LI $(\mathrm{r}=0.65)$, similarly to $\mathrm{HD}(\mathrm{r}=0.48$ for $\mathrm{O}$ and $\mathrm{r}=0.62$ for $\mathrm{LI})$, but the negative correlations of GY to GPC and TAR were found to be a level stronger in $\mathrm{O}(\mathrm{r}=-0.73$ and -0.63 , respectively) than in $\mathrm{LI}(\mathrm{r}=-0.51$ and -0.51 , respectively). Weaker, but also negative correlation was detected between $\mathrm{PH}$ and GPC, which was 


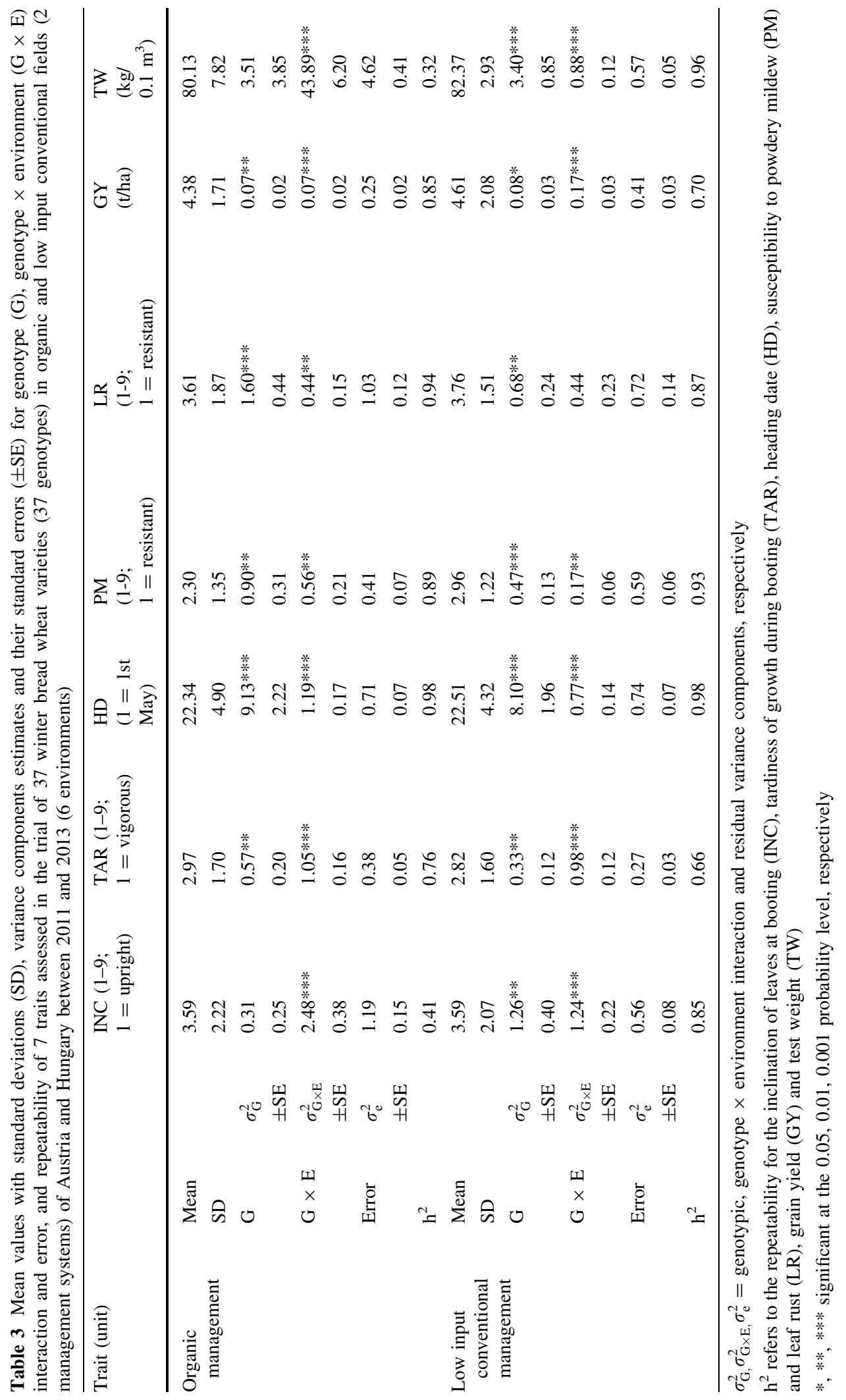




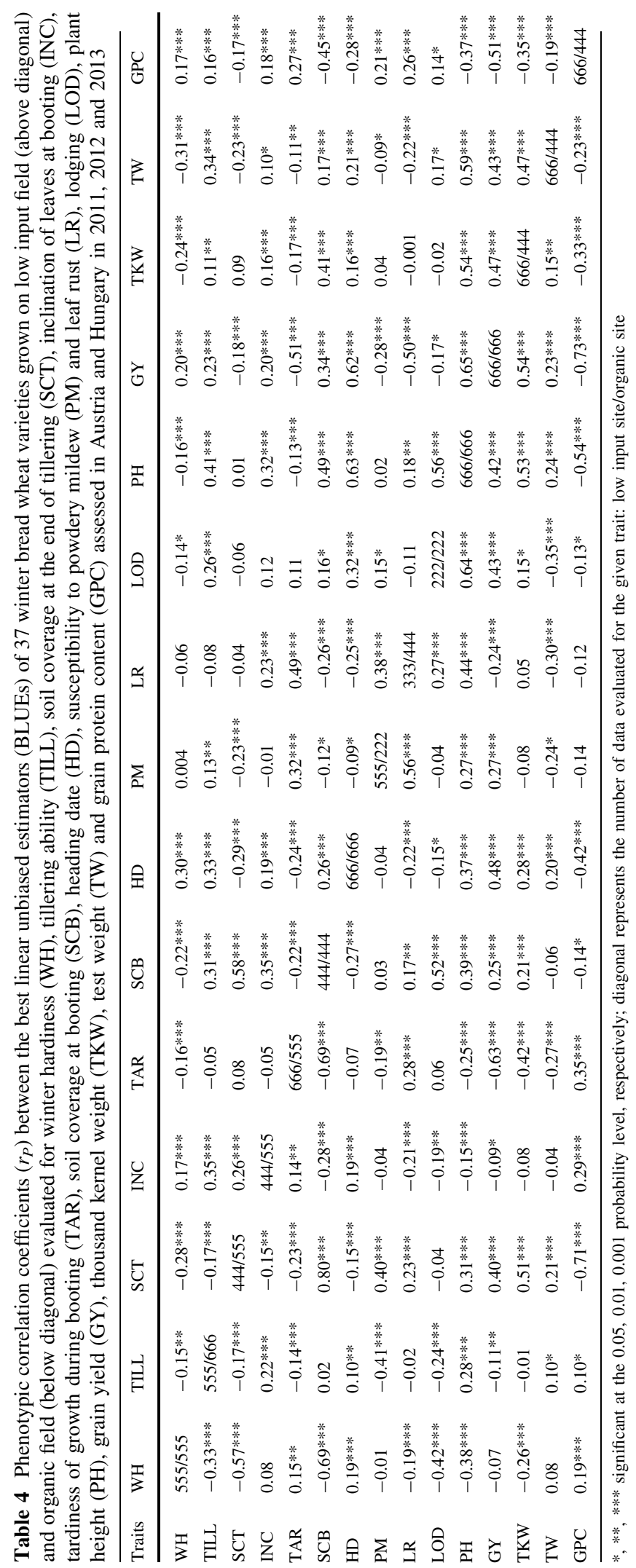


moderate in $\mathrm{O}(\mathrm{r}=-0.54)$ and weak (almost moderate) in LI system $(r=-0.37)$.

Differences in the strength of the correlations were also found between the management systems for some pairs of traits. TAR and SCB correlated strongly negatively in organic field $(r=-0.69)$, but this correlation was weak in the other management system $(\mathrm{r}=-0.22)$, and similarly GPC and HD showed moderate negative correlation in $\mathrm{O}$ field $(\mathrm{r}=-0.42)$, but weak in LI field $(r=-0.28)$. Severity of disease symptoms of PM and LR was found to be moderately strong correlated in $\mathrm{O}$ field $(\mathrm{r}=0.56)$, while this positive correlation was weak in LI field $(r=0.38)$. By contrast, positive correlation between LR and TAR was detected as moderately strong in LI field $(\mathrm{r}=0.49)$, but it was weak in $\mathrm{O}$ field $(\mathrm{r}=0.28)$, and, similarly, positive correlation between $\mathrm{PH}$ and HD was found to be strong in LI $(r=0.63)$, and weak in $\mathrm{O}(\mathrm{r}=0.37)$. Two TW-connected positive correlations also showed these differences: its correlation to GY was detected as moderate in LI $(r=0.43)$ and weak in $\mathrm{O}(\mathrm{r}=0.23)$, as well as the correlation to TKW was found to be moderate in LI $(r=0.47)$ and very weak in $\mathrm{O}$ field $\left(\mathrm{r}=0.15^{* *}\right)$.

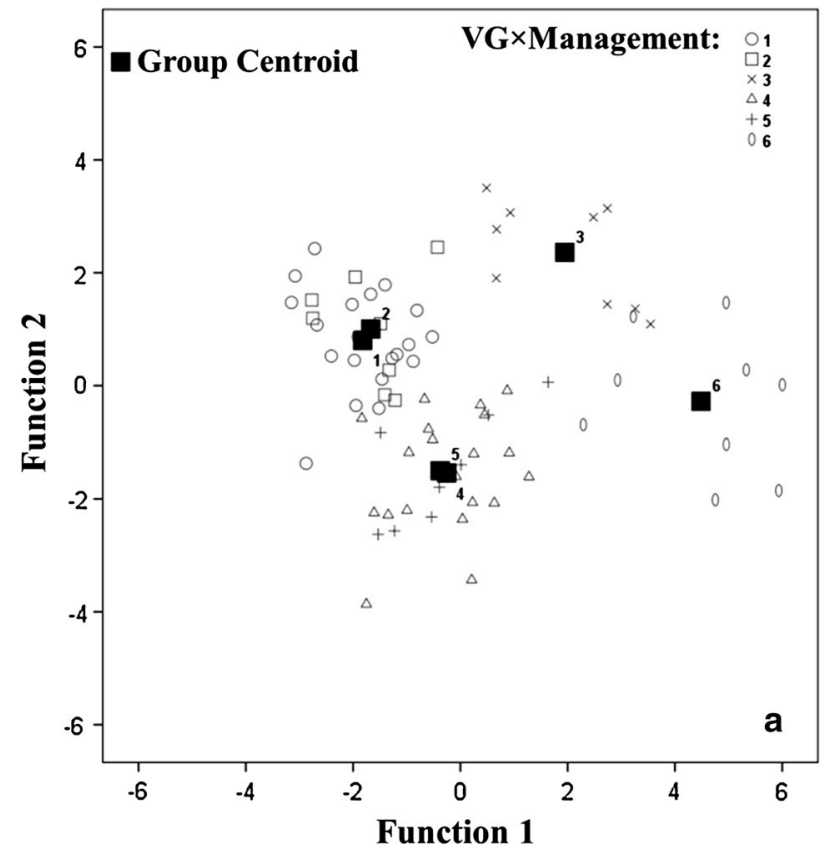

Fig. 1 Combined groups plot $\mathbf{a}$ and classification results $\mathbf{b}$ of discriminant analysis of 15 traits assessed on 37 winter bread wheat varieties with three different breeding origins [organic, conventional and BFOA variety-group (VG)] in organic $(\mathrm{O})$ and low input conventional (LI) management systems of Austria and
Discrimination of VGs

A discriminant function analysis was carried out in order to determine how the variety-groups differed from each other in $\mathrm{O}$ and LI fields with respect to their performance based on 15 traits (Fig. 1). The first two discriminant functions together accounted for $85.3 \%$ of the total variance. $\mathrm{PH}(\mathrm{r}=0.59)$, LOD $(\mathrm{r}=0.46)$, $\mathrm{HD}(\mathrm{r}=0.36)$, GY $(\mathrm{r}=-0.35)$ and GPC $(\mathrm{r}=0.13)$ had the largest significant $(p<0.05)$ correlation within Function 1 (58.9\% of the total variance), while only SCB $(r=0.33)$ had significant correlation within Function 2 (26.4\% of the total variance). Not only the $\mathrm{O}$ (group 4, 5 and 6) and LI (group 1, 2 and 3) management systems could be clearly discriminated from each other, but also the different groups of varieties developed on the basis of their breeding origin. Moreover, the discriminant analysis also showed that the group of organically bred varieties (group 3 and 6) was very different from the conventional (group 1 and 4) and BFOA (group 2 and 5) varieties at both sites, while the conventional and BFOA varieties showed great overlapping among each other (Fig. 1a). Based on the 15 traits assessed in two

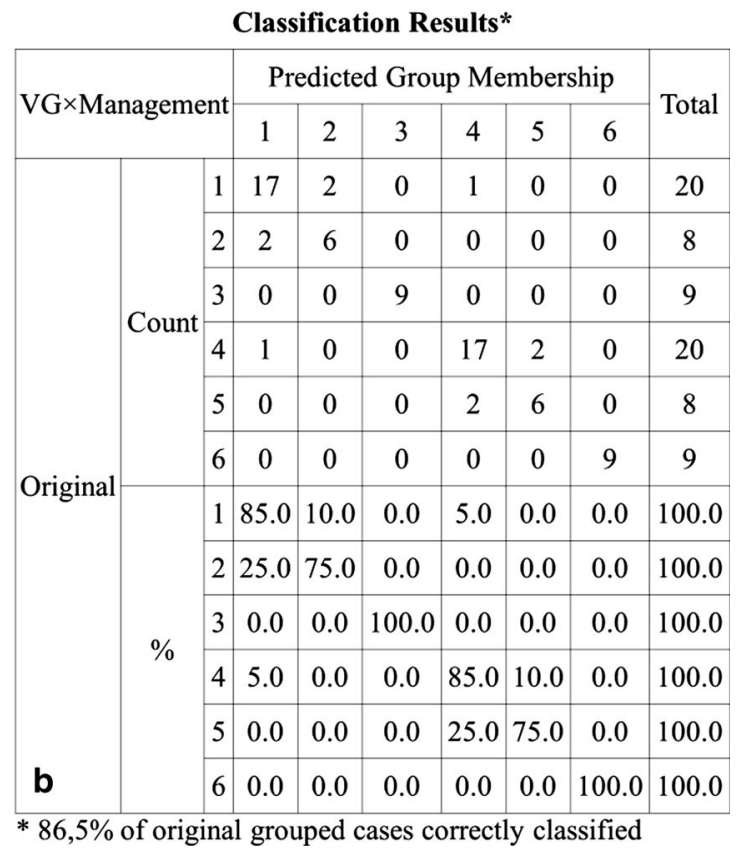

Hungary between 2011 and 2013. The six VG $\times$ Management groups are conventional VG in LI (1), BFOA VG in LI (2), organic VG in LI (3), conventional VG in O (4), BFOA VG in O (5) and organic VG in $\mathrm{O}(6)$ 
management systems for 3 years in two countries we could correctly classify all the nine organic varieties on organic (group 6) and low input (group 3) fields. In a total of $86.5 \%$ of the original grouped varieties were correctly classified, because some BFOA varieties were grouped in the conventional variety-group (group 1 and 4) proving that they were bred in a similar conventional way in the early generations (Fig. 1b).

\section{Discussion}

\section{Variety performance}

In the present study most of the 15 traits assessed on 37 bread wheat varieties showed strong $\mathrm{G} \times$ E interaction, except soil coverage (SCT and SCB), which was mainly affected by the different environmental conditions rather than the genotypes itself. According to Menzi and Anders (2002) from the set of traits studied in our experiments, three traits are already included in the official organic VCU tests for bread wheat, namely the SCT, SCB and INC. Present study failed to give evidence for the different effects of genotype on soil coverage, but could give in the case of leaf-inclination, which is very important trait for competing against weeds. The large $\mathrm{G} \times \mathrm{E}$ interaction under variable farming conditions will still have great impact on variety performance, which can be decreased by the decentralisation of breeding and/or by participatory plant breeding (Murphy et al. 2005; Dawson et al. 2011). Another possible solution could be the increasing of the buffering capacity through the increased genetic diversity of the wheat crop using varietymixtures or composite cross populations (Wolfe 1985; Finckh et al. 2000; Döring et al. 2011).

Based on the significant $\mathrm{M} \times \mathrm{G}$ interactions, seven traits (INC, TAR, HD, PM, LR, GY and TW) were found to be efficient indicators for examining the differences between the performance of varieties grown under organic and low input conventional growing conditions. The less GY and the lower TW in organic fields could be the consequence of the lower nutrient supply. In contrary, this deficiency was resulted in lower PM infection in organic fields as a consequence of the less dense stands, documented by the lower SCB values (Suppl. Table 3). In the case of the other traits, the slightly higher deviations detected in organic system could also be a result of the more extreme growing conditions on organic fields than on the conventional low input fields. Despite PH being strongly significant $(p<0.001)$ for the main effects, no significant $\mathrm{M} \times \mathrm{G}$ interaction could be detected (Table 2). Nevertheless on the VG level in a six sites average we could observe that organic varieties were taller than conventionally bred ones with $23 \%$ $\left(p=5.10 \times 10^{-9}\right)$ and $26 \%\left(p=5.10 \times 10^{-9}\right)$ in organic and low input fields, respectively (Suppl. Table 3), which is in line with the report of Wolfe et al. (2008). In organic farming, plant height is an essential trait in competing against weeds (Gooding et al. 1993; Mason and Spaner 2006) or diseases (especially fusarium head blight, if ears are developed far above the canopy) (Hilton et al. 1999) through the enhanced ground coverage and shading effect. This study could demonstrate the effectiveness of this organic breeding target through the organic varieties taken under examination. However PH had strong positive correlation with LOD in organic field, in practice lodging is less frequent on organic sites where mostly less fertilizer is applied compared to conventional ones. GY had strong negative correlation with GPC in organic field and moderate, negative correlation in LI field, which is in line with previous quality studies (e.g. Sissons 2008; Longin et al. 2013). This and the other relatively strong correlations (PH-GY, HD-GY, TKW-GY) could be affected not only by the genotype, but also by the extreme dry seasons, which resulted in shorter stand, earlier heading date, less filled grain (lower TKW), lower yield and higher protein content. Only TAR seemed to be independent from the climatic conditions, as its strong, negative correlation to GY showed that those varieties had higher yield, which had more vigorous spike-development during booting, known to be more intensive (lower TAR) in dry seasons when GY is also lower. Some other traits selected on the basis of having significant $\mathrm{M} \times \mathrm{G}$ interaction showed unbalanced correlation among each other regarding the two management systems (e.g. PM-LR $[+]$ for stronger positive correlation in $\mathrm{O}$ than in LI field and TAR-LR [+], TW-GY [+] or LRGY [-] for stronger correlation in LI than in $\mathrm{O}$ ) proving that these traits are strongly affected by the management system and could be useful in a separate organic wheat breeding approach. 
Repeatability and breeding goals

The repeatability $\left(\mathrm{h}^{2}\right)$ approach fulfilled our expectation about the traits known to be highly heritable from previous studies (e.g. Löschenberger et al. 2008), because $\mathrm{h}^{2}$ for HD, PM and LR in the average of the two management systems were $0.98,0.91$ and 0.91 , respectively. Therefore, early stage selection could be based on them during organic breeding. Moreover, some studies also recommend for economic reasons to use a combined strategy for breeding for OA, selecting the material for highly heritable traits in the early generations in (mainly low input) conventional fields, and further selections should be carried out under organic growing conditions for the less heritable traits (Oberforster 2003; Przystalski et al. 2008; Löschenberger et al. 2008; Wolfe et al. 2008; Baenziger et al. 2011). Present study showed that INC, TW, TAR (refers to vigorousness) and also GY could be among these secondary selection targets that should be kept in mind in organic system. Besides, a high positive effect of alternating the selection between stressed and nonstressed environments on the adaptability and stability of the bread wheat breeding lines was proved by many studies (e.g. Le Gouis et al. 2000; Kirigwi et al. 2004; Saulescu et al. 2005). This adaptability is based on a high degree of buffering capacity derived from the allohexaploid genome of wheat (Udall and Wendel 2006). The best varieties for OA therefore could be selected in the later generations in organic systems with direct selection (BFOA) and not in conventional fields using indirect selection; these findings are highlighted by the present study and also by previous studies (Murphy et al. 2007; Wolfe et al. 2008). Although seed-borne diseases were not observed during the first 2 years of the ring test, the severe infection of common bunt found on all the varieties in the 3rd year revealed the urgent need for targeted selection of organic wheat breeding lines against this harmful disease. But as a first step of breeding for disease resistance, the overall plant health and robustness through phenotypic characters should be ensured.

Evidence for the distinctness of organic wheat breeding

Based on the assessment of 15 traits through 3 years in 2 countries, the present study has demonstrated the distinctness of organic breeding both in organic and low input fields compared to the common conventional wheat breeding, which showed similar performance to the combined technique of BFOA. Conventional and BFOA varieties showed great overlapping, because the early generations of the BFOA varieties were selected in conventional system. These findings could give evidence for that the environment where the selection is carried out has great influence on the traits of bread wheat breeding lines. Therefore, the organic wheat breeding is resulted in different varieties than the other breeding strategies. However, as the various traits examined in the present study point out the main agronomic and selection differences between the variety-groups bred with different breeding strategies (see Suppl. Table 3), a more detailed evaluation is planned to be carried out including the compositional and processing quality traits of the studied varieties in the near future.

Acknowledgments This research received funding from the European Community's Seventh Framework Programme (FP7/ 2007-2013) under the Grant Agreement No 245058-SOLIBAM (supplementary Hungarian project EU_BONUS_12-1-20120032), and from two Hungarian National Science and Technology Office projects (TECH_O8-A3/2-2008-0397CONFU_O8 and TECH_O8-A3/2-2008-0423-ALKOBEER).

Open Access This article is distributed under the terms of the Creative Commons Attribution License which permits any use, distribution, and reproduction in any medium, provided the original author(s) and the source are credited.

\section{References}

Baenziger PS, Salah I, Little RS, Santra DK, Regassa T, Wang MY (2011) Structuring an efficient organic wheat breeding program. Sustainability 3:1190-1205

Baresel JP, Reents HJ (2006) Observations on long-term wheat variety trials under organic and conventional conditions in Germany. In: Østergard H, Fontaine L (eds) Proceedings of the COST SUSVAR workshop on cereal crop diversity: implications for production and products. ITAB Press, Paris, pp 83-87

Cormier F, Faure S, Dubreuil P, Heumez E, Beauchêne K, Lafarge S, Praud S, Le Gouis J (2013) A multi-environmental study of recent breeding progress on nitrogen use efficiency in wheat (Triticum aestivum L.). Theor Appl Genet 126:3035-3048

Dawson JC, Rivière P, Berthellot J-F, Mercier F, de Kochko P, Galic N, Pin S, Serpolay E, Thomas M, Giuliano S, Goldringer I (2011) Collaborative plant breeding for 
organic agricultural systems in developed countries. Sustainability 3:1206-1223

Döring TF, Knapp S, Kovács G, Murphy K, Wolfe MS (2011) Evolutionary plant breeding in cereals: into a new era. Sustainability 3:1944-1971

Döring TF, Bocci R, Hitchings R, Howlett S, Lammerts van Bueren ET, Pautasso M, Raaijmakers M, Rey F, Stubsgaard A, Weinhappel M, Wilbois KP, Winkler LR, Wolfe MS (2012) The organic seed regulations framework in Europe: current status and recommendations for future development. Org Agric 2:173-183

Eisele J-A, Köpke U (1997) Choice of cultivars in organic farming: new criteria for winter wheat ideotypes. II. Weed competitiveness of morphologically different cultivars. Pflanzenbauwissenschaften 1:84-89

Evans JD (1996) Straightforward statistics for the behavioural sciences. Brooks/Cole Pub. Co., Pacific Grove 600 p

Finckh MR, Gacek ES, Goyeau H, Lannou C, Merz U, Mundt CC, Munk L, Nadziak J, Newton AC, de Vallavieille-Pope C, Wolfe MS (2000) Cereal variety and species mixtures in practice, with emphasis on disease resistance. Agronomie 20:813-837

Gooding MJ, Thompson AJ, Davies WP (1993) Interception of photosynthetically active radiation, competitive ability and yield of organically grown wheat varieties. Asp Appl Biol 34:355-362

Hilton AJ, Jenkinson P, Hollins TW, Parry DW (1999) Relationship between cultivar height and severity of Fusarium ear blight in wheat. Plant Pathol 48:202-208

Hoad S, Neuhoff D, Davies K (2005) Field evaluation and selection of winter wheat for competitiveness against weeds. In: Lammerts van Bueren ET, Goldringer I, Østergard H (eds) Organic plant breeding strategies and the use of molecular markers, Proceedings of the COSTSUSVAR/ECO-PB Workshop, Jan 17-19. Louis Bolk Institute, Driebergen, The Netherlands, 61-66

Kirigwi FM, van Ginkel M, Trethowan R, Sears RG, Rajaram S, Paulsen GM (2004) Evaluation of selection strategies for wheat adaptation across water regimes. Euphytica 135:361-371

Lammerts van Bueren ET, Jones SS, Tamm L, Murphy KM, Myers JR, Leifert C, Messmer MM (2010) The need to breed crop varieties suitable for organic farming, using wheat, tomato and broccoli as examples: a review. NJAS Wagening J Life Sci 58:193-205

Le Gouis J, Béghin D, Heumez E, Pluchard P (2000) Genetic differences for nitrogen uptake and nitrogen utilisation efficiencies in winter wheat. Eur J Agron 12:163-173

Longin CFH, Sieber AN, Reif JC (2013) Combining frost tolerance, high grain yield and good pasta quality in durum wheat. Plant Breed 132:353-358

Löschenberger F, Fleck A, Grausgruber H, Hetzendorfer H, Hof G, Lafferty J, Marn M, Neumayer A, Pfaffinger G, Birschitzky J (2008) Breeding for organic agriculture: the example of winter wheat in Austria. Euphytica 163:469-480

Mason HE, Spaner D (2006) Competitive ability of wheat in conventional and organic management systems: a review of the literature. Can J Plant Sci 86:333-343

Menzi M, Anders M (2002) Variety tests with winter wheat and winter barley under organic agricultural conditions. Agrarforschung (J Swiss Agric Res) 9:60-64

Murphy K, Lammer D, Lyon S, Carter B, Jones SS (2005) Breeding for organic and low-input farming systems: an evolutionary-participatory breeding method for inbred cereal grains. Renew Agric Food Syst 20:48-55

Murphy KM, Campbell KG, Lyon SR, Jones SS (2007) Evidence of varietal adaptation to organic farming systems. Field Crops Res 102:172-177

Oberforster M (2003) Verfahren der Wertprüfung für den ökologischen Landbau in Österreich. In: Bundessortenamt (ed) Sortenwertprüfungen für den ökologischen Landbau, Workshop, May 14-15, Hannover, Germany, 20-27

Presterl T, Seitz G, Landbeck M, Thiemt EM, Schmidt W, Geiger HH (2003) Improving nitrogen-use efficiency in European maize: estimation of quantitative genetic parameters. Crop Sci 43:1259-1265

Przystalski M, Osman A, Thiemt EM, Rolland B, Ericson L, Østergard H, Levy L, Wolfe M, Büchse A, Piepho HP, Krajewski P (2008) Comparing the performance of cereal varieties in organic and non-organic cropping systems in different European countries. Euphytica 163:417-433

Saulescu NN, Ittu G, Mustatea P, Simion G (2005) Improved nitrogen response as an objective in wheat breeding. Roman Agric Res 22:1-4

Schwaerzel R, Levy L, Menzi M, Anders M, Winzeler H, Dörnte J (2006) Winterweizensorten im biologischen und extensiven Anbau. Agrarforschung 13:68-73

Sissons M (2008) Role of durum wheat composition on the quality of pasta and bread. Food 2:75-90

Udall JA, Wendel JF (2006) Polyploidy and crop improvement. Crop Sci 46:3-14

Vida G, Szunics L, Veisz O, Bedő Z, Láng L, Árendás T, Bónis P, Rakszegi M (2014) Effect of genotypic, meteorological and agronomic factors on the gluten index of winter durum wheat. Euphytica 197:61-71

Virk DS, Pandit DB, Sufian MA, Ahmed F, Siddique MAB, Samad MA, Rahman MM, Islam MM, Ortiz-Ferrara G, Joshi KD, Withcombe JR (2009) REML is an effective analysis for mixed modelling of unbalanced on-farm varietal trials. Exp Agric 45:77-91

Wolfe MS (1985) The current status and prospects of multiline cultivars and variety mixtures for disease control. Ann Rev Phytopathol 23:251-273

Wolfe MS, Baresel JP, Desclaux D, Goldringer I, Hoad S, Kovács G, Löschenberger F, Miedaner T, Østergard H, Lammerts van Bueren ET (2008) Developments in breeding cereals for organic agriculture. Euphytica 163:323-346 